ppi $201502 Z U 4645$

Esta publicación cientifica en formato digital es continuidad de la revista impresa ISSN-Versión Impresa 0798-1406 / ISSN-Versión on line 2542-3185Depósito legal pp

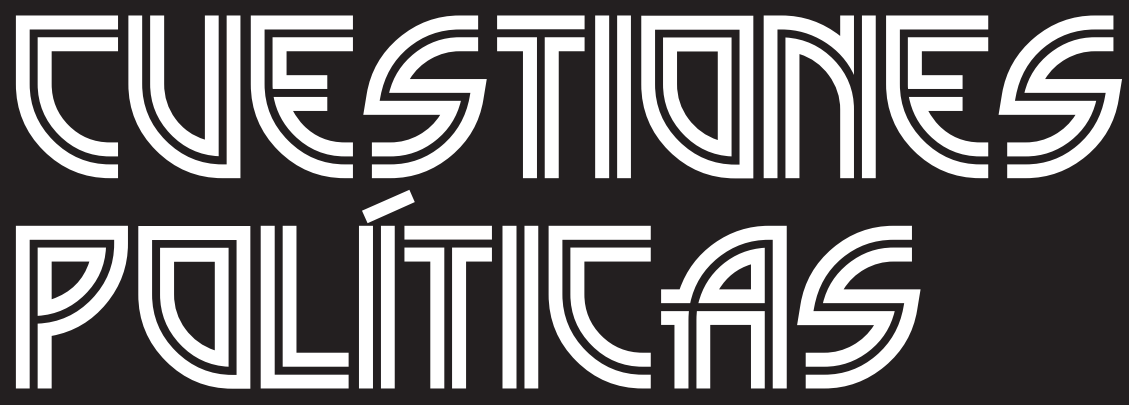

Instituto de Estudios Políticos y Derecho Público "Dr. Humberto J. La Roche' de la Facultad de Ciencias Jurídicas y Políticas de la Universidad del Zulia Maracaibo, Venezuela
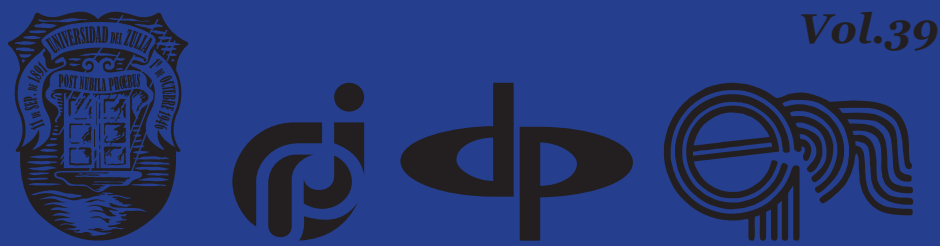


\title{
Economic and financial results of the USA and the European Union sanctions war against Russia: first results
}

\author{
DOI: https://doi.org/10.46398/cuestpol.3968.16
}

\author{
Ilmir Nusratullin * \\ Raul Yarullin ** \\ Tagira Ismagilova *** \\ Olga Eremeeva $* * * *$ \\ Tatiana Ermoshina $* * * * *$
}

\section{Abstract}

As part of this study, the goal is set to assess the impact of sanctions imposed by the United States and the European Union on the economy and financial sector of Russia, to identify the effectiveness of the initial goals of these countries. To achieve the goal, the legal acts concerning the imposed sanctions of the USA and the European Union against Russia were first analyzed, a chronology of events was described, and sanctions were classified. Further, based on the data of the World Bank and the Federal State Statistics Service of the Russian Federation, the results of the sanction pressure on the Russian economy and financial sector were estimated. Then the results of this study were compared with the results obtained by other scholars. The paper concluded that the sanctions of the United States and the European Union did have an impact on the economy and financial sector of Russia, but this influence was not as significant as the leaders of these countries expected. In addition, the impact of the sanctions is gradually decreasing despite the introduction of new sanctions on various pretexts.

Keywords: Sanctions against Russia; economic war; financial pressure for sanctions; economic sanctions; geopolitical economy.

* Bashkir State University, Russia. ORCID ID: https://orcid.org/oooo-ooo1-7810-2945. Email: nusratullin.iv@gmail.com

** Financial University under the Government of the Russian Federation, Russia. ORCID ID: https:// orcid.org/oooo-ooo1-6834-3032. Email: jrr61@mail.ru

*** Financial University under the Government of the Russian Federation, Moscow, Russia. ORCID ID: https://orcid.org/oooo-0oo2-2747-3858. Email: tagira_i@mail.ru

**** Katanov State University of Khakassia, Russia. ORCID ID: https://orcid.org/oooo-ooo1-9258-4610. Email: yeremeevaos@yandex.ru

***** Ogarev Mordovia State University, Republic of Mordovia. ORCID ID: https://orcid.org/oooo-0oo34575-8969. Email: baricheva@mail.ru 
Ilmir Nusratullin, Raul Yarullin, Tagira Ismagilova, Olga Eremeeva y Tatiana Ermoshina 252

Economic and financial results of the USA and the European Union sanctions war against Russia: first results

\section{Resultados económicos y financieros de la guerra de sanciones de Estados Unidos y la Unión Europea contra Rusia: primeros resultados}

\section{Resumen}

Se estableció el objetivo de evaluar el impacto de las sanciones impuestas por Estados Unidos y la Unión Europea sobre la economía y el sector financiero de Rusia, para identificar la efectividad de los objetivos iniciales de estas sanciones. Para lograr este objetivo, se analizaron los actos jurídicos relativos a las sanciones impuestas por EE. UU. y la Unión Europea contra Rusia, se realizó una cronología de los hechos descritos y las sanciones se clasificaron, de ahí que se hizo uso del método analítico y de la revisión documental. Además, sobre la base de los datos del Banco Mundial y el Servicio de Estadísticas del Estado de la Federación de Rusia, se estimaron los resultados de la presión de las sanciones sobre la economía. Luego, los resultados de este estudio se compararon con los resultados obtenidos por otros académicos. El documento concluyó que las sanciones de Estados Unidos y la Unión Europea sí tuvieron un impacto en la economía y el sector financiero de Rusia, pero esta influencia no fue tan significativa como esperaban los líderes de estos países. Además, el impacto de las sanciones está disminuyendo gradualmente a pesar de la introducción de nuevas sanciones con diversos pretextos.

Palabras clave: Sanciones contra Rusia; guerra económica; presión financiera de sanciones; sanciones económicas; economía geopolítica.

\section{Introduction}

Economic warfare is a form of political and competitive struggle in which economic measures weaken or destroy the economic potential of some country. Modern politicians understand that the physical extermination of enemies is not always profitable; it is more advantageous to build a system of economic dependence and, through control over the enemy's resources and its sales markets, make it work for oneself. The economic war has as its alternative goal the "peaceful" conquest and retention of new economic markets (Evsyakova, 2019).

The main principle of economic warfare is the establishment of dependent economic relations, and in the case of resistance, even the inclusion of physical forms of influence, state pressure and extortion under the threat of the use of armed forces. For this, modern developed countries have at their disposal special force, intelligence, ideological, psychological, etc. structures. At the present stage, economic warfare is carried out mainly 
in three directions: "brain pumping", economic expansion, and industrial espionage (Titova, 2006). It can also be carried out by using various propaganda slogans such as the struggle for democracy, the environment, the rights of national minorities, and others. In this case, it is closely connected with the information war (Maan, 2014; Meshcheriakova, 2018). In addition, economic warfare is closely linked to big politics, as it is the key to depriving "inconvenient" governments of public support (Martynenko, 2016).

Economic sanctions, suspension of loans from developed countries and major international financial and credit organizations pose great difficulties for the economy of the "delinquent" countries, most often the "developing" ones. The United States and European countries, pursuing an aggressive foreign policy towards developing countries, prefer to avoid using the term "economic warfare". The ruling establishment of the United States and its allies use such neutral words as "economic sanctions", "trade and economic restrictions", "moratorium", "prohibitions", etc. (Kaempfer and Lowenberg, 2007). However, as a rule, all these restrictions, moratoriums, and prohibitions taken together can have a powerful effect, designed to undermine a national economy, provoke social unrest, change of power and political course (Neuenkirch and Neumeier, 2015).

In general, the modern economic warfare is a confrontation between two powers or different blocs against each other or against a separate country using economic sanctions - an embargo on the export/import of new technologies, high-tech goods, partial or complete trade blockade. Methods such as the collapse of the national currency, of the prices of the main exported natural resources (especially oil and gas), and of various industrial and agricultural goods are also used. The totality of economic sanctions that the West imposed against Russia from 2012 to the present can be qualified as full-scale economic warfare.

In Neuenkirch and Neumeier (Neuenkirch and Neumeier, 2015), it was empirically assessed how economic sanctions imposed by the United Nations and the United States affected the GDP growth of sanctioned states. In that study, they analyzed 160 countries, of which 67 were subject to economic sanctions for the period 1976-2012. The authors found that UN sanctions had a significant impact on the economic growth of the target state. On average, the introduction of the UN sanctions reduces the annual growth rate of real GDP per capita in such a state by more than 2 percentage points. These negative consequences last for 10 years and lead to an overall decrease in the national GDP per capita by $25.5 \%$. The comprehensive economic UN sanctions, that is, embargoes affecting almost all economic activity, lead to a decrease in GDP growth of more than 5 percentage points. The effect of the US sanctions is much smaller and less noticeable. The imposition of the US sanctions reduces the GDP growth of the target state 
Ilmir Nusratullin, Raul Yarullin, Tagira Ismagilova, Olga Eremeeva y Tatiana Ermoshina 254

Economic and financial results of the USA and the European Union sanctions war against Russia:

by $0.75^{-1}$ percentage point. This detrimental effect on growth persists for 7 years and, together, leads to a decrease in GDP of $13.4 \%$.

The objective of this study is to first assess the impact of sanctions imposed by the United States and the European Union on the economy and the financial sector of Russia, and to identify whether these countries have achieved their initial goals.

To achieve the objective, the following tasks have been set:

1. To reveal the history of the sanctions confrontation between the USA, the European Union, and Russia;

2. To give the main characteristics of the imposed sanctions;

3. To reveal the economic and financial consequences for Russia from the sanctions confrontation.

\section{Materials and Methods}

While preparing this paper, regulatory legal acts governing the imposition of sanctions were analyzed. These are regulations databases of the US (https://obamawhitehouse.archives.gov/briefing-room/legislation), the EU (https://europa.eu/european-union/law_en), and Russia (http:// pravo.gov.ru/ips/). To assess the impact of sanctions on the economies of the countries, the materials of the World Bank (data.worldbank.org/), and the Federal State Statistics Service of the Russian Federation (https://www. gks.ru/) were used. In addition, the paper used materials from academic articles of the ScienceDirect database (https://www.sciencedirect.com/).

The study was conducted as follows:

1. First, regulations on the imposed sanctions by the United States and the European Union against Russia were analyzed, a chronology of events was described, and the sanctions were classified.

2. Further, based on the data of the World Bank and the Federal State Statistics Service of the Russian Federation, the results of the sanction pressure on the Russian economy and the financial sector were estimated.

3. Then the results of the study were compared with the results of studies by other scholars.

\section{Results}

The history of the sanctions confrontation of the United States, the European Union and Russia 
According to the provisions of international law, sanctions are coercive measures of an armed and unarmed nature that are applied by subjects of international law in the established procedural form in response to an offense in order to prevent it, restore the violated rights and ensure the responsibility of the offender. Thus, sanctions are coercive measures applied to a state that violated international legal obligations (Neshataeva, 1992). Sanctions are inextricably linked with the institution of international legal responsibility of states - "the responsibility of states for internationally wrongful acts".

The history of the application of sanctions imposed in the world from 1915 to 2000 totals 174 cases, of which: the USA imposed sanctions in 109 cases, the UN in 20 cases, the European Union in 14 cases, the United Kingdom in 16 cases, the Arab League states and its members - in 4 cases, the Soviet Union and Russia - in 13 cases (Hufbauer et al., 2007).

The modern "sanction warfare" against Russia began in 2012, when the adoption of the Magnitsky Act in the USA formally repealed the JacksonVanik Amendment to the US Trade Act. The Act gave the President of the United States the right to set the list of persons responsible for the detention, ill-treatment and death of Sergey Magnitsky and other serious human rights violations in the Russian Federation that are subject to sanctions (the ban on the entry into the United States of such persons; the freezing of assets and the prohibition of any transactions in connection with the transfer of all property and property rights of such persons) (Public law, 2012).

The second wave of the anti-Russian sanctions falls on the period of the political crisis in Ukraine in 2014-2019. In addition, the United States and the European Union imposed sanctions against Russia in connection with the support of the Governments of Venezuela and Syria, cooperation with Iran and the DPRK. One should also recall the scandal about alleged Russian interference in US elections and the Skripals case.

After classifying the reasons for the imposition of sanctions against Russia, they look as follows (according to the US and the EU regulations):

1. The Magnitsky Act of 2012. Large-scale sanctions against Russia began to be introduced in 2013 due to the death of a Russian auditor Sergey Magnitsky. In the West, they believe that his death in 2009 was caused by the exposure of corruption schemes for tax returns, which could have involved Russian officials and security forces. The Magnitsky Act, originally directed against persons who, in the opinion of the American authorities, could have been involved in the death of the auditor, later began to apply to those responsible for violating human rights and the rule of law both in Russia and around the world. 


\section{Ilmir Nusratullin, Raul Yarullin, Tagira Ismagilova, Olga Eremeeva y Tatiana Ermoshina 256 Economic and financial results of the USA and the European Union sanctions war against Russia:}

2. The conflict in Ukraine - the situation around Crimea. The most ambitious sanctions are related to the annexation of Crimea to Russia and events in the east of Ukraine.

3. Cyber-attacks. Sanctions for cyber-attacks were introduced by Barack Obama on April 1, 2015. They allow the U.S. Treasury Department to block in the country any assets of individuals suspected of committing cyber-attacks.

4. Opponents of America. On August 2, 2017, US President Donald Trump signed the Countering America's Adversaries Through Sanctions Act (CAATSA). It imposes additional restrictions on Iran, North Korea and Russia.

5. For ties with Syria, Venezuela, and the DPRK. The smallest groups of sanctions against Russia are those for supporting the Governments of Syria and Venezuela and deals with the DPRK authorities.

6. The Skripals case. On August 27, 2018, the sanctions entered into force that do not directly affect individuals or legal entities. They are connected with the poisoning of the ex-colonel of the GRU Sergey Skripal and his daughter Julia in British Salisbury.

The economic sanctions of the USA and Western countries, applied in recent years against Russia, can be regarded only as a return to the sanctions campaign during the Cold War against the Soviet Union. The noted sanctions have become a common foreign policy tool of Western countries, one of the elements of the Russia containment strategy. Moreover, in many respects, the introduction of the sanctions is connected with far-fetched reasons, not confirmed even during investigations, for example, cyber-attacks during the US presidential election.

\subsection{Key features of the US and the EU sanctions}

According to the type of sanctions, then they can be classified as (Bagheri and Akbarpour, 2016):

1. Personal - sanctions against particular people (officials, participants in conflicts, businessmen, company managers, etc.) who are prohibited from entering the territory of the country imposing sanctions, as well as freezing assets.

2. Against companies/organizations - sanctions against particular companies and organizations that are prohibited from operating in the country imposing sanctions, as well as with its companies and organizations, and freezing of assets. 
3. Economic-economic measures of a prohibitive nature in the field of trade and economic cooperation.

4. Financial - a set of prohibitive measures in the field of finance and financial cooperation.

5. Diplomatic - a set of measures of a prohibitive nature in the field of political cooperation.

Classifying the sanctions by the countries that introduced them, the situation is as follows (Table 1 ).

\begin{tabular}{|l|l|}
\hline \multicolumn{1}{|c|}{ Country } & \multicolumn{1}{c|}{ Sanctions imposed } \\
\hline Australia & $\begin{array}{l}\text { Supported the US sanctions, introduced sanctions lists } \\
\text { against citizens and companies of the Russian Federation }\end{array}$ \\
\hline Albania & Joined the individual and general EU sanctions \\
\hline Georgia & $\begin{array}{l}\text { Canceled several interstate meetings. Refused to impose } \\
\text { other sanctions }\end{array}$ \\
\hline Israel & Banned the supply of weapons and military technology \\
\hline Iceland & Joined the majority of individual and general EU sanctions \\
\hline Liechtenstein & Joined the majority of individual and general EU sanctions \\
\hline Moldova & $\begin{array}{l}\text { Joined the majority of the EU sanctions, banned } \\
\text { broadcasting of several Russian TV channels }\end{array}$ \\
\hline Norway & $\begin{array}{l}\text { Consistently, joined the EU sanctions, canceled military } \\
\text { and economic cooperation }\end{array}$ \\
\hline New Zealand & $\begin{array}{l}\text { Introduced personal sanctions, supported Australia in } \\
\text { banking sanctions }\end{array}$ \\
\hline Ukraine & $\begin{array}{l}\text { Joined the majority of individual and general EU sanctions, } \\
\text { banned broadcasting of Russian TV channels }\end{array}$ \\
\hline Switzerland & Introduced individual and economic sanctions \\
\hline Montenegro & Supported part of the EU individual and general sanctions \\
\hline Japan & $\begin{array}{l}\text { Stopped visa mitigation negotiations, disputed territory } \\
\text { negotiations, introduced individual and economic } \\
\text { sanctions }\end{array}$ \\
\hline
\end{tabular}

Table 1. Countries supporting the US and the EU sanctions against Russia

Source: (RIA, 2020). 
Ilmir Nusratullin, Raul Yarullin, Tagira Ismagilova, Olga Eremeeva y Tatiana Ermoshina 258

Economic and financial results of the USA and the European Union sanctions war against Russia:

Further, let us consider the list of economic, financial, and diplomatic sanctions imposed by the US and the EU from 2014 to 2020 (Table 2).

\begin{tabular}{|c|c|c|}
\hline $\begin{array}{l}\text { Reason/ } \\
\text { Type of } \\
\text { sanctions }\end{array}$ & Ukraine/Crimea & The Skripals poisoning \\
\hline Economic & $\begin{array}{l}\text { Licensing of US exports of } \\
\text { defense goods and services to } \\
\text { Russia terminated in the USA } \\
\text { (2014) } \\
\text { In the US, it is forbidden to } \\
\text { sell high-tech goods to Russia } \\
\text { that could enhance the combat } \\
\text { readiness of the army (2014) } \\
\text { The EU imposed an embargo on } \\
\text { the import and export of weapons } \\
\text { to Russia, a ban on the export of } \\
\text { dual-use goods and technologies } \\
\text { for military use (2014) } \\
\text { In the USA, the supply of } \\
\text { equipment and technologies to } \\
\text { the deep oil and gas production, } \\
\text { development of the Arctic shelf } \\
\text { and production of shale oil and gas } \\
\text { reserves to Russia was prohibited } \\
\text { (2014) } \\
\text { U.S. Department of Defense was } \\
\text { banned from allocating funds for } \\
\text { military cooperation with Russia } \\
\text { (2016) }\end{array}$ & $\begin{array}{l}\text { The supply of foreign aid } \\
\text { to Russia, with the exception } \\
\text { of emergency humanitarian } \\
\text { aid, was terminated. } \\
\text { The supply of food and } \\
\text { agricultural products, the } \\
\text { sale of arms and any defense } \\
\text { goods, defense services, } \\
\text { design and construction } \\
\text { services were stopped. The } \\
\text { US also refuses to issue any } \\
\text { loans and credit guarantees } \\
\text { to Russia. The US may } \\
\text { tighten these sanctions if } \\
\text { Moscow does not provide } \\
\text { guarantees for the non-use } \\
\text { of chemical and biological } \\
\text { weapons (2018) }\end{array}$ \\
\hline Financial & $\begin{array}{l}\text { The US investment and military } \\
\text { cooperation with Russia frozen } \\
\text { (2014) } \\
\text { The European Investment Bank } \\
\text { stopped financing projects in } \\
\text { Russia (2014) } \\
\text { A ban was introduced in } \\
\text { the EU on investments in the } \\
\text { infrastructure, transport and } \\
\text { energy sectors, as well as oil and } \\
\text { gas production in the Russian } \\
\text { Federation (2014) } \\
\text { The EU investments in Crimea } \\
\text { and Sevastopol (2014) were } \\
\text { prohibited. }\end{array}$ & $\begin{array}{l}\text { The US requires } \\
\text { international financial } \\
\text { organizations not to provide } \\
\text { Russia with anyinternational } \\
\text { loans or financial/technical } \\
\text { assistance. The Government } \\
\text { also prohibits any US bank } \\
\text { from granting any loans } \\
\text { or credits to the Russian } \\
\text { government - with the } \\
\text { exception of loans or credits } \\
\text { intended to purchase food or } \\
\text { other agricultural goods or } \\
\text { products (2019) }\end{array}$ \\
\hline
\end{tabular}




\begin{tabular}{|c|c|c|}
\hline Diplomatic & $\begin{array}{l}\text { The EU - Russia Summit } \\
\text { canceled (2014) } \\
\text { The EU embassies in Russia } \\
\text { are forbidden to issue visas to } \\
\text { residents of Crimea (2014) } \\
\text { The work of the Russian- } \\
\text { American Presidential Commission } \\
\text { (2014) was terminated }\end{array}$ & $\begin{array}{l}\text { The US and its allies } \\
\text { announced the expulsion of } \\
\text { Russian diplomats. Twenty- } \\
\text { nine countries together } \\
\text { expelled more than 150 } \\
\text { Russian diplomats and } \\
\text { diplomatic representatives. } \\
\text { The US expelled more } \\
\text { Russians than all, over 6o } \\
\text { people, followed by the UK - } \\
\text { 23 people (2018) }\end{array}$ \\
\hline
\end{tabular}

Table 2. Economic, financial and political sanctions of the US and the EU from 2014 to 2020

Source: (Ageev and Yarmoshchuk, 2020)

As can be seen from the table, the most painful sanctions of the US and the EU are those in the field of technical and scientific cooperation, in the field of banning financing of Russia and companies and organizations from Russia by financial organizations of the West, except for short-term loans.

Next, let us consider the individual sanctions and sanctions against companies and organizations imposed by the US and the EU (Table 3).

\begin{tabular}{|c|c|c|}
\hline Reason for imposing sanctions & $\begin{array}{c}\text { Number } \\
\text { of citizens } \\
\text { of Russia }\end{array}$ & $\begin{array}{c}\text { Number of } \\
\text { companies and } \\
\text { organizations }\end{array}$ \\
\hline $\begin{array}{c}\text { The death of Sergey Magnitsky, corruption } \\
\text { and violation of human rights }\end{array}$ & 57 & 1 \\
\hline $\begin{array}{c}\text { Annexing of Crimea and events in the east } \\
\text { of Ukraine }\end{array}$ & 286 & 478 \\
\hline Cyber-attacks vs the US & 27 & 11 \\
\hline $\begin{array}{c}\text { Sanctions under the Countering America's } \\
\text { Adversaries Through Sanctions Act } \\
\text { (CAATSA) }\end{array}$ & 32 & 42 \\
\hline Supporting the Government of Syria & 12 & 6 \\
\hline Supporting the Government of Venezuela & 0 & 3 \\
\hline $\begin{array}{c}\text { Sale of goods or weapons to the DPRK, } \\
\text { Iran, and Syria }\end{array}$ & 6 & 11 \\
\hline The Skripals case & 4 & 0 \\
\hline
\end{tabular}

Table 3. The number of legal entities and individuals subject to sanctions (data in the lists may be duplicated)

Source: (Sapronova et al., 2020). 
Ilmir Nusratullin, Raul Yarullin, Tagira Ismagilova, Olga Eremeeva y Tatiana Ermoshina 260 Economic and financial results of the USA and the European Union sanctions war against Russia:

More sanctions against people and companies have been introduced due to the annexation of Crimea and events in eastern Ukraine, as well as within the framework of the Countering America's Adversaries Through Sanctions Act.

From April 12, 2013 to January 9, 2017, the US President Barack Obama imposed sanctions against 555 citizens and companies of Russia; from June 1, 2017 to March 12, 2020, US President Donald Trump imposed sanctions against 260 citizens and companies of Russia (Sapronova et al., 2020). More details are displayed in Figures 1 and 2.

Most of all, the separatist forces of the DPR and the LPR (23\%), the Russian security/military chiefs (23\%), politicians (13\%), businessmen (14\%), and officials (14\%) fell under sanctions.

Most companies and organizations under the sanctions of the US and the EU are the fuel and energy sector (25\%), banks (22\%), and defense companies (12\%).

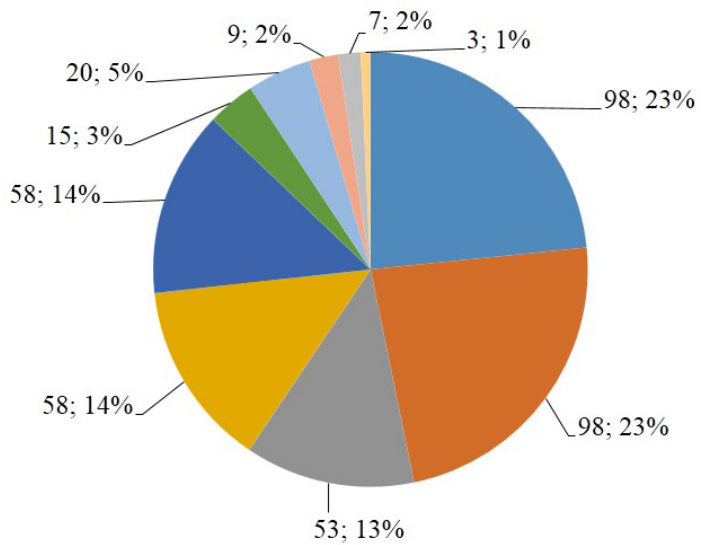

- Separatist forces of the DPR, LPS, Novorossiya $\quad$ Security/military chiefs

- Politicians

- Officials

- Large companies' CEOs

$\square$ Public figures
- Businessmen

- Trolls factory

versons suspected of human rights violations

Other

Source: (Sapronova et al., 2020)

Figure 1. The structure of citizens subject to the US and the EU sanctions (data given on the number and as a percentage of the total share) 


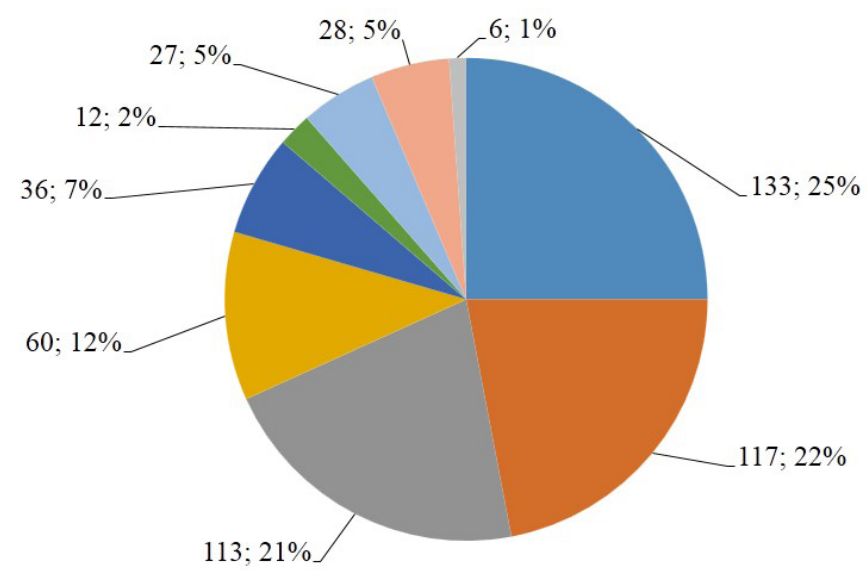

- Fuel and energy sector

- Other companies

- Transport

- Construction

State authorities

$$
\begin{aligned}
& \text { Banks } \\
& \text { Defense companies } \\
& \text { Investment and insurance companies } \\
& \text { Public organizations }
\end{aligned}
$$

Source: (Sapronova et al., 2020)

Figure 2. Structure of companies and organizations subject to the US and the EU sanctions (data given on the number and as a percentage of the total share).

In general, based on the US and the EU regulations, sanctions against Russia can be divided into blocking (in the USA this is the SDN (Specially Designated Nationals) list and sectoral (in the USA this is the SSI (Sectoral Sanctions Identifications) list.

When subject to blocking sanctions, the assets of individuals and companies, both in the US and in the EU, are blocked. It is forbidden to conduct any business and transactions with them. Sanctioned individuals are prohibited from entering the US and/or the EU.

Sectoral sanctions apply to particular individuals operating in certain sectors of the economy, as well as to companies owned or controlled by such individuals.

Assets of companies included in the sectoral sanctions list are not frozen, unlike those in the SDN list. In the banking sector, getting into such a list 
Ilmir Nusratullin, Raul Yarullin, Tagira Ismagilova, Olga Eremeeva y Tatiana Ermoshina 262 Economic and financial results of the USA and the European Union sanctions war against Russia:

does not imply isolation of these companies from the financial system only the restrictions on the provision of new financing by the US and the EU companies apply. In practice, this means that, for example, banks that fall under sectoral sanctions will not be able to attract loans from banks and investors, whether it be bonds or credits. Moreover, the ban does not apply to debts for a period of less than 14 days (for the US sanctions) and 30 days (for the EU sanctions).

In the defense sector, persons and companies subject to the US sanctions have been banned from importing and exporting weapons and related materials, dual-use goods and services from/to Russia. For those included in the sanctions lists of the EU members, there is a ban on the purchase, sale, transfer, and export of arms and ammunition to Russia by the EU residents, as well as a ban on the export of dual-use goods (goods that can be used both for peaceful purposes and for creating weapons of mass destruction) and technology for military use.

In the energy sector, persons and companies that have fallen under the US sanctions have been banned from exporting to Russia goods, services or technologies related to exploration and production of oil on the Arctic shelf, deep-sea production, and shale projects (the energy sector). For the EU sanctioned lists, a licensing procedure has been introduced for transactions with Russia in relation to goods and technologies intended for the extraction and exploration of oil and other mineral wealth.

Certain legal acts may provide for exceptions in the form of limiting the effect of sanctions in the implementation of particular operations.

Economic and financial results for Russia of the US and the EU sanctions.

Further, by the example of several indicators, one may study how the sanctions of the US and the EU affected the Russian economy and financial sector.

First, let us consider the indicator of the gross domestic product at current prices and prices in a particular year (Table 4). 
CUESTIONES POLÍTICAS

Vol. 39 No 68 (Enero - Junio 2021): 251-272

\begin{tabular}{|c|c|c|c|c|c|c|c|c|}
\hline & 2012 & 2013 & 2014 & 2015 & 2016 & 2017 & 2018 & 2019 \\
\hline $\begin{array}{l}\text { GDP at } \\
\text { current } \\
\text { prices, } \\
\text { billion } \\
\text { rubles }\end{array}$ & $\begin{array}{l}68,103 \\
.4\end{array}$ & $\begin{array}{l}72,985 \\
.7\end{array}$ & $\begin{array}{l}79,030 \\
.0\end{array}$ & $\begin{array}{l}83,087 \\
.4\end{array}$ & $\begin{array}{l}85,616 \\
.1\end{array}$ & $\begin{array}{l}91,843 \\
.2\end{array}$ & $\begin{array}{l}104,629 \\
.6\end{array}$ & $\begin{array}{l}110,046 \\
.1\end{array}$ \\
\hline $\begin{array}{l}\text { GDP at } \\
2016 \text { prices, } \\
\text { billion } \\
\text { rubles }\end{array}$ & $\begin{array}{l}85,040 \\
.3\end{array}$ & $\begin{array}{l}86,533 \\
.1\end{array}$ & $\begin{array}{l}87,170 \\
.2\end{array}$ & $\begin{array}{l}85,450 \\
.6\end{array}$ & $\begin{array}{l}85,616 \\
.1\end{array}$ & $\begin{array}{l}87,179 \\
.3\end{array}$ & $\begin{array}{l}89,390 \\
.4\end{array}$ & $\begin{array}{l}90,589 \\
.9\end{array}$ \\
\hline $\begin{array}{l}\text { Consumer } \\
\text { price index } \\
\text { for goods } \\
\text { and services, } \\
\%\end{array}$ & 106.57 & 106.47 & 111.35 & 112.91 & 105.39 & 102.51 & 104.26 & 103.04 \\
\hline
\end{tabular}

Table 4. Gross domestic product at current prices and prices in 2016, billion rubles

Considering GDP at current prices, its dynamics are positive over the period from 2012 to 2019, the growth being $61.6 \%$. It is also worth noting that during the period of the imposition of foreign sanctions, the dynamics of GDP growth at current prices decreased, but was positive overall. However, GDP at current prices does not reflect the real situation, since in Russia throughout the whole period from 2012 to 2019 there was significant inflation, its fluctuations ranged from 3.04 to $12.91 \%$. In this regard, it is necessary to consider the dynamics of GDP at the prices of a particular year, for example, 2016.

GDP at 2016 prices shows that the dynamics are not so rosy. GDP growth amounted to only $6.5 \%$ for the period from 2012 to 2019. In 2015-2016, there was a decrease in GDP. However, in 2017, GDP growth at 2016 prices resumed. This is illustrated more clearly in Figure 3.

\begin{tabular}{|c|c|c|c|c|c|c|c|c|}
\hline \multirow{2}{*}{$\begin{array}{l}120000,0 \\
100000,0\end{array}$} & & & & & \multicolumn{2}{|r|}{91843,2} & 104629,6 & $\underset{\rightarrow}{110046,1}$ \\
\hline & 85040,3 & 86533,1 & 87170,2 & 85450,6 & 85616,1 & & & \multirow{3}{*}{90589,9} \\
\hline 80000,0 & & & & 83087,4 & \multirow{2}{*}{\multicolumn{2}{|c|}{87179,3}} & 89390,4 & \\
\hline 60000,0 & 68103,4 & 72985,7 & 79030,0 & & & & & \\
\hline \multicolumn{9}{|l|}{40000,0} \\
\hline \multicolumn{9}{|l|}{20000,0} \\
\hline 0,0 & 2012 & 2013 & 2014 & 2015 & 2016 & 2017 & 2018 & 2019 \\
\hline & & -GDP at cu & prices, bi & rubles & IDP at 20 & 6 prices, bil & rubles & \\
\hline
\end{tabular}

Source: (Rosstat, 2020).

Figure 3. Gross domestic product at current prices and at prices of 2016, billion rubles 
Ilmir Nusratullin, Raul Yarullin, Tagira Ismagilova, Olga Eremeeva y Tatiana Ermoshina 264

Economic and financial results of the USA and the European Union sanctions war against Russia:

It should be noted that the decline in Russia's GDP in the indicated period is explained not only by the influence of the foreign sanctions, but also to a greater extent by a decrease in the cost of oil in the world market (Figure 4).

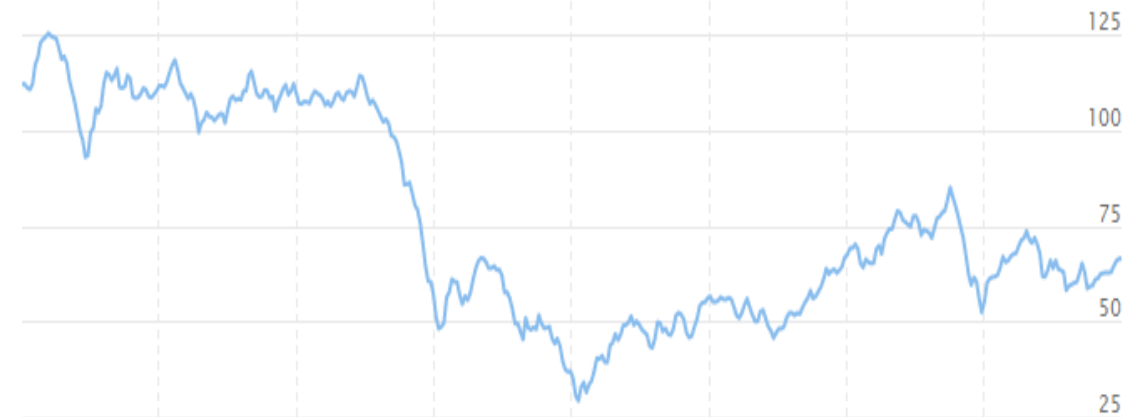

$\begin{array}{llllllll}2012 & 2013 & 2014 & 2015 & 2016 & 2017 & 2018 & 2019\end{array}$

Source: (Rosstat, 2020).

Figure 4. Dynamics of oil prices in the world market from 2012 to 2019

A 2-fold decrease in the cost of oil in 2015-2016 led to a decrease in the export earnings of most Russian oil and gas (Gazprom, as the gas prices in most contracts are tied to the oil prices) companies. However, these losses for the Russian budget were offset by the depreciation of the ruble against the dollar from 39 rubles/ $\$$ to almost 80 rubles $/ \$$. Modern research boils down to the fact that the decline in Russia's GDP in 2015-2016 was mainly due to a drop in the cost of oil, and not to the imposed sanctions (Korotin et al., 2019).

In general, considering the dynamics of the industrial production index after the introduction of the main effective measures of sanction pressure, the performance of Russia looks more positive than in the countries that imposed sanctions against Russia, especially compared to Ukraine, France, and the UK (Table 5). 


\begin{tabular}{|l|l|l|l|}
\hline & 2016 & 2017 & 2018 \\
\hline Russia & 113.3 & $115 \cdot 7$ & 119 \\
\hline Ukraine & 83 & 83 & 84 \\
\hline Germany & 112 & 116 & 117 \\
\hline United Kingdom & 100.2 & 102 & 103 \\
\hline France & 100.5 & 102 & 103 \\
\hline USA & 108 & 111 & 115 \\
\hline
\end{tabular}

Source: (Rosstat, 2020).

Table 5. Industrial production indices, \%

The most significant measures of sanction pressure on Russia were the sanctions in the field of technological and scientific cooperation, against the business and the financial sector. Let us consider their consequences now.

In the period from 2012 to 2019 in Russia, the share of high-tech and knowledge-intensive industries in the gross domestic product was slowly growing from 20.2 to $21.6 \%$, in 2015 and 2016 there was a slight decrease to 21.1 and $21.3 \%$, respectively. Judging by an increase in highly productive jobs in \% compared to the previous year, in 2015 and 2016 there was an outflow, in other years there was an inflow (Table 6). Thus, the effect of sanctions, if it was in 2015 and 2016, then decreased by 2017.

\begin{tabular}{|l|l|l|l|l|l|l|l|l|}
\hline & 2012 & 2013 & 2014 & 2015 & 2016 & 2017 & 2018 & 2019 \\
\hline $\begin{array}{l}\text { Share of high-tech } \\
\text { and knowledge- } \\
\text { intensive industries } \\
\text { in the gross domestic } \\
\text { product, \% of the } \\
\text { total }\end{array}$ & 20.2 & 21.0 & 21.6 & 21.1 & 21.3 & 21.8 & 21.1 & 21.6 \\
\hline $\begin{array}{l}\text { Increase in highly } \\
\text { productive jobs, \% } \\
\text { compared to the } \\
\text { previous year }\end{array}$ & 12.7 & 6.9 & 4.5 & -9.1 & -4.8 & 7.1 & 14.7 & 5.6 \\
\hline
\end{tabular}

Source: (Rosstat, 2020).

Table 6. Development of high-tech and knowledge-intensive industries in Russia 
Ilmir Nusratullin, Raul Yarullin, Tagira Ismagilova, Olga Eremeeva y Tatiana Ermoshina 266

Economic and financial results of the USA and the European Union sanctions war against Russia:

Further, let us consider the operational performance of medium and large companies in Russia (Table 7).

\begin{tabular}{|lccc|c|c|c|c|c|}
\hline & 2012 & 2013 & 2014 & 2015 & 2016 & 2017 & 2018 & $2019^{*}$ \\
$\begin{array}{l}\text { Balance of profit } \\
\text { and loss, billion } \\
\text { rubles } \\
\text { in \% to the }\end{array}$ & 7,824 & 6,854 & 4,347 & 7,503 & 12,801 & 9,037 & 12,400 & 15,758 \\
$\begin{array}{l}\text { corresponding } \\
\text { period of the } \\
\text { previous year }\end{array}$ & 110.8 & 82.7 & 68.2 & 173.6 & 157.0 & 69.5 & 159.6 & 117.5 \\
$\begin{array}{l}\text { Profit amount } \\
\text { Proportion } \\
\text { of profitable } \\
\text { organizations, \% }\end{array}$ & 9,213 & 9,519 & 10,465 & 12,654 & 15,823 & 14,079 & 18,332 & 17,696 \\
$\begin{array}{l}\text { Loss amount } \\
\text { Proportion of } \\
\text { unprofitable } \\
\text { organizations, \% }\end{array}$ & 1,389 & 2,665 & 6,118 & 5,151 & 3,022 & 5,042 & 5,932 & 1,938 \\
\hline
\end{tabular}

Source: (Rosstat, 2020).

Table 7. Operational performance of medium and large companies in Russia.

If one considers the overall economic performance of medium and large companies in Russia in 2012-2019, in general there was a positive trend, growth was observed except for 2013, 2014 and 2017. The amount of profit tended to increase. In 2014, a decrease in profitability was visible, which may be caused by the imposed sanctions and a decrease in the cost of oil in the world market, followed by devaluation of the ruble.

Further, let us consider the performance of banks in Russia (Table 8).

\begin{tabular}{|l|l|l|l|l|l|l|l|l|}
\hline & 2012 & 2013 & 2014 & 2015 & 2016 & 2017 & 2018 & 2019 \\
\hline $\begin{array}{l}\text { Total profit (+)/ } \\
\text { loss (-) received } \\
\text { by existing credit } \\
\text { institutions, } \\
\text { million rubles }\end{array}$ & $\begin{array}{l}1,011 \\
.9\end{array}$ & 993.6 & 589.1 & 192.0 & 929.7 & 789.7 & $\begin{array}{l}1,344 \\
.8\end{array}$ & $\begin{array}{l}2,036 \\
.8\end{array}$ \\
\hline
\end{tabular}




\begin{tabular}{|l|l|l|l|l|l|l|l|l|}
\hline $\begin{array}{l}\text { Profit volume } \\
\text { of credit } \\
\text { institutions with } \\
\text { profit, million } \\
\text { rubles }\end{array}$ & $\begin{array}{l}1,021 \\
.3\end{array}$ & $\begin{array}{l}1,012 \\
.3\end{array}$ & 853.2 & 735.8 & $\begin{array}{l}1,291 \\
.9\end{array}$ & $\begin{array}{l}1,561 \\
.6\end{array}$ & $\begin{array}{l}1,919 \\
.4\end{array}$ & $\begin{array}{l}2,196 \\
.4\end{array}$ \\
\hline $\begin{array}{l}\text { Proportion of } \\
\text { existing credit } \\
\text { organizations } \\
\text { that had profit, \% }\end{array}$ & 94.2 & 90.5 & 84.9 & 75.4 & 71.4 & 75.0 & 79.3 & 84.4 \\
\hline $\begin{array}{l}\text { Losses volume } \\
\text { of credit } \\
\text { institutions } \\
\text { that had losses, } \\
\text { million rubles }\end{array}$ & 9.4 & 18.7 & 264.1 & 543.8 & 362.2 & 772.0 & 574.6 & 159.6 \\
\hline $\begin{array}{l}\text { Proportion of } \\
\text { existing credit } \\
\text { organizations } \\
\text { that had losses, } \\
\%\end{array}$ & 5.8 & 9.5 & 15.1 & 24.6 & 28.6 & 25.0 & 20.7 & 15.6 \\
\hline
\end{tabular}

Table 8. Performance of banks in Russia

The impact of the sanctions on the Russian banking sector is clearer. During the period of the introduction of the main sanctions by the US and the EU in 2014-2015, the profitability of banks was sharply reduced (by 5 times in 2015 compared to 2012), but already in 2018 and 2019, it was recovering and sharply increasing (a 2-fold increase on 2012). However, it is too early to talk about the restoration of the banking sector in Russia, since there is still a high proportion of loss-making banks (15.6\% in 2019 compared to $5.8 \%$ in 2012).

Now, let us consider the dynamics of imports and exports in Russia (Figure 5).

Analyzing the dynamics of exports and imports in Russia, it is worth noting that their decline began back in 2012, and in 2014-2016 it only intensified. The fall in exports and imports is primarily due to the situation in the oil market, the devaluation of the ruble, and the introduction of foreign sanctions. However, the trend has been changing since 2017, when exports and imports growth in Russia began. 
Ilmir Nusratullin, Raul Yarullin, Tagira Ismagilova, Olga Eremeeva y Tatiana Ermoshina 268

Economic and financial results of the USA and the European Union sanctions war against Russia: first results

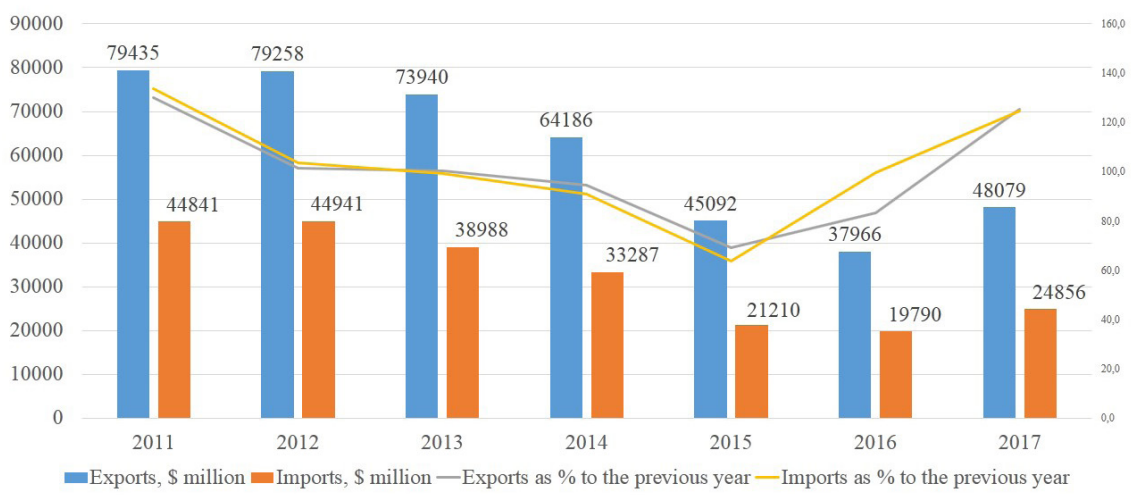

Source: (Rosstat, 2020).

Figure 5. Dynamics of imports and exports in Russia

Thus, the impact of sanctions on the economy and the financial sector of Russia was observed only from 2014 to 2016, then this effect was reduced. That is, the effectiveness of the sanction pressure is gradually decreasing despite the introduction of new sanctions under various pretexts.

\section{Discussion and Conclusion}

The results obtained in this study are similar to those obtained earlier. Thus, in (Nusratullin et al., 2020a, 2020b), during an analysis of industrial and socio-economic development, a decrease in the sanction effect on the Russian industry and the public standard of living was revealed. In addition, somewhat positive trends were identified in the operation of the Russian manufacturing industry. It was concluded in the above studies that today for Russia, the strategic tasks were reduced to overcoming technological backwardness and carrying out technological modernization of the manufacturing industries based on the use of innovative achievements, as well as import substitution of the economy sectors that are sensitive to the foreign sanctions.

(Bayramov et al., 2020), considering the Western sanctions against Russia, attempted to assess the medium-term effects of these sanctions on Russia's post-communist neighbors. In the course of that study, the scholars came to the conclusion that the Western sanctions against Russia had a significant impact on the economy of neighbors - the CIS countries. However, this influence also decreased over time. 
Korotin et al., (2019) put that the sanctions imposed against Russia in 2014 coincided with a shock in the oil market. It is believed that both the sanctions and the falling oil prices affected the ruble exchange rate, which depreciated by 2 times compared to the pre-crisis level. The authors, evaluating the effect of the sanctions on the ruble exchange rate, came to the conclusion that there was no direct effect of the sanctions on the ruble exchange rate.

(Dong and $\mathrm{Li}, 2018$ ) analyzed the US and the EU economic sanctions against Russia and concluded that all countries involved in the sanctions would suffer, but comparatively Russia would suffer more, while the US and the EU would suffer less. The EU sanctions have a greater impact on Russia than the US measures, meantime, the Russian sanctions will have a greater impact on the EU than on the US. From an economic point of view, the optimal choice for the US and the EU is to abandon the sanctions against Russia, while the retaliatory sanctions are Russia's optimal choice when it is faced with sanctions. The countries offside the sanctions will benefit from the trade diversion effect.

(Gurvich and Prilepskiy, 2015) examined the impact of the Western financial sanctions on the Russian economy. Modeling the components of the capital flow (taking into account the influence of other factors, including falling oil prices) showed that sanctions directly affected banks, oil, gas and weapons companies in Russia, severely limiting funding from abroad by reducing the flow of foreign direct investment and worsening the financing conditions. The total negative impact on gross capital inflows for 20142017 was estimated at approximately $\$ 280$ billion. The predicted impact of the sanctions on GDP was estimated at -2.4 percentage points by 2017 compared to the hypothetical scenario without sanctions, but this is 3.3 times lower than the estimated impact of the oil price shock.

(Ankudinov et al., 2017) examined the impact of the sanctions on the Russian stock market. The results showed that for almost all industry indicators, a statistically significant increase in volatility was observed. At the same time, the study does not have sufficient data on structural changes in the stock market. The changes in the stock market cannot be directly related to the sanctions imposed; the latter can be largely caused by higher country-specific risks due to geopolitical tensions and the volatility of oil prices.

Thus, in this study and in the studies by fellow scholars, some results were obtained acknowledging that the sanctions of the US and the EU did have an impact on the economy and the financial sector of Russia, but this impact was not as significant as the leaders of these countries expected. In addition, the impact of the sanctions is gradually decreasing despite the introduction of new sanctions on various pretexts. 
Ilmir Nusratullin, Raul Yarullin, Tagira Ismagilova, Olga Eremeeva y Tatiana Ermoshina 270

Economic and financial results of the USA and the European Union sanctions war against Russia: first results

\section{Bibliographic References}

AGEEV, Mikhail; YARMOSHCHUK, Tatiana. 2020. All U.S. and European Union sanctions against Russia since 2014. In: Online project of "Novoe Vremya". Available online. In: https://www.currenttime.tv/a/russiaamerican-european-sanctions/29449693.html. Consultation date: 10/03/2020.

ANKUDINOV, Andrei; IBRAGIMOV, Rustam; LEBEDEV, Oleg. 2017. "Sanctions and the Russian stock market" In: Research in International Business and Finance. Vol. 40, pp. 150-162.

BAGHERI, Sajjad; AKBARPOUR, Hamdi Reza. 2016. "Reinvestigation of the West's Sanctions against Russia in the Crisis of Ukraine and Russia's Reaction" In: Procedia Economics and Finance. Vol, 36, pp. 89-95.

BAYRAMOV, Vugar; RUSTAMLI, Nabi; ABBAS, Gulnara. 2020. "Collateral damage: The Western sanctions on Russia and the evaluation of implications for Russia's post-communist neighbourhood" In: International Economics. Vol. 162, pp 92-109.

DONG, Yan; LI, Chunding. 2018. "Economic sanction games among the US, the EU and Russia: Payoffs and potential effects" In: Economic Modelling. Vol. 73, pp. 117-128.

EVSYAKOVA, Alexandra Alexeevna. 2019. "Sanctions as an element of economic war. Legal aspects of application" In: Spirit Time. Vol. 15, No. 3-1, pp. 45-46. Available online. In: https://www.elibrary.ru/download/ elibrary_38512717_21728951.pdf (in Russian). Consultation date: 10/03/2020.

GURVICH, Evsey; PRILEPSKIY, Ilya. 2015. "The impact of financial sanctions on the Russian economy” In: Russian Journal of Economics. Vol. 1, No. 4, pp. 359-385.

HUFBAUER, Gary Clyde; SCHOTT, Jeffrey; ELLIOTT, Kimberly Ann; OEGG, Barbara. 2007. Economic Sanctions Reconsidered. Peterson Institute for International Economics. Washington, DC, USA.

KAEMPFER, William; LOWENBERG, Anton. 2007. Chapter 27: The Political Economy of Economic Sanctions. Handbook of Defense Economics, editor(s): Todd Sandler, Keith Hartley. Elsevier. Amsterdam, Netherlands.

KOROTIN, Vladimir; DOLGONOSOV, Maxim; POPOV, Victor; KOROTINA, Olesya; KOROLKOVA, Inna. 2019. "The Ukrainian crisis, economic sanctions, oil shock and commodity currency: Analysis based on EMD 
approach” In: Research in International Business and Finance. Vol. 48, pp. 156-168.

MAAN, Amer. 2014. "Features of methods and techniques of conducting information warfare during the Middle East crisis of 2010-2012" In: Innovation and investment. No. 2, pp 101-105. Available online. In: https://www.elibrary.ru/item.asp?id=22409842 (in Russian). Consultation date: 10/03/2020.

MARTYNENKO, Elena Viktorovna. 2016. "The nature of the information war between Russia and The United States in Syria" In: Society: politics, economics, law. Vol. 9, No. 9-12. Available online. In: https://www. elibrary.ru/download/elibrary_26702570_31096169.pdf (in Russian). Consultation date: 23/02/2020.

MESHCHERIAKOVA, Victoria Gennadievna. 2018. "Information warfare launched in foreign media against Russia as an example of "participation" hacker attacks during the 2016 U.S. presidential election" In: National interests: priorities and security. Vol 14, No. 1, pp. 2149-2161. Available online. In: https://www.elibrary.ru/download/ elibrary_36408928_15576608.pdf (in Russian). Consultation date: 23/02/2020.

NESHATAEVA, Tatyana Nikolaevna. 1992. UN system sanctions (international legal aspect). Publishing House of Irkutsk State University. Irkutsk, Russia.

NEUENKIRCH, Matthias; NEUMEIER, Florian. 2015. "The impact of UN and US economic sanctions on GDP growth" In: European Journal of Political Economy. Vol. 40, Part A, pp 110-125.

NUSRATULLIN, Ilmir; KUZNETSOVA, Svetlana; GAZIZYANOVA, Yuliya; KUTSENKO, Ekaterina; BEREZHNAYA, Luvob. 2020a. "Socioeconomic development of Russia in terms of the BRICS countries' development" In: Amazonia Investiga. Vol. 9, No. 27, pp. 52-61.

NUSRATULLIN, Ilmir; SERGEEV, Nikolai; KUZNETSOV, Maxim; SHEINA, Anastasia; SHUBTSOVA, Lyudmila. 2020b. "Industrial development under sanctions pressure: evidence from Russia” In: Amazonia Investiga. Vol. 9, No. 28, pp. 465-474.

PUBLIC LAW. 2012. 112-208 -DEC. 14, 2012. Russia and Moldova JacksonVanik Repeal and Sergei Magnitsky Rule of Law Accountability Act of 2012. 19 USC 2101 note. Available online. In: https://www.treasury. gov/resource-center/sanctions/Programs/Documents/pl112_208.pdf. Consultation date: 23/02/2020. 
Ilmir Nusratullin, Raul Yarullin, Tagira Ismagilova, Olga Eremeeva y Tatiana Ermoshina

RIA. 2020. Sanctions lists against Russian citizens and companies. RIA News Agency. Available online: https://ria.ru/20140718/1016514535.html. Consultation date: 10/04/2020.

ROSSTAT. 2020. Official Statistics of the Russian Federation. Available online. In: https://www.gks.ru/folder/10705 (in Russian). Consultation date: 10/04/2020.

SAPRONOVA, Yulia; LINDELL, Dada; ANTIPOVA, Anastasia; TKACHEV, Ivan; HIMSHIASHVILI, Polina. 2020. Six years of sanctions against Russia. The main thing. News Agency Ros. Biznes.Consulting. Available online. In: https://www.rbc.ru/politics/16/o3/2020/5bffbofo9a79470 ff5378627. Consultation date: 10/04/2020.

TITOVA, Elena. 2006. "Economic war: Origins, Substance, Strategies" In: Scientific works of the Free Economic Society of Russia. Vol. 64, pp. 114124. Available online. In: http://veorus.ru/upload/iblock/59f/64_veor. pdf (in Russian). Consultation date: 10/04/2020. 

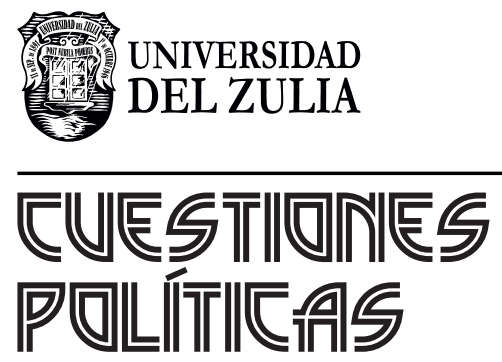

Vol.39 No 68

Esta revista fue editada en formato digital y publicada en enero de 2021, por el Fondo Editorial Serbiluz, Universidad del Zulia. Maracaibo-Venezuela 